\title{
Optimal Design of DC Fast-Charging Stations for EVs in Low Voltage Grids
}

\author{
Gjelaj, Marjan; Træholt, Chresten; Hashemi Toghroljerdi, Seyedmostafa; Andersen, Peter Bach
}

Published in:

Proceedings of 2017 IEEE Transportation Electrification Conference

Link to article, DOI:

10.1109/ITEC.2017.7993352

Publication date:

2017

Document Version

Peer reviewed version

Link back to DTU Orbit

Citation $(A P A)$ :

Gjelaj, M., Træholt, C., Hashemi Toghroljerdi, S., \& Andersen, P. B. (2017). Optimal Design of DC FastCharging Stations for EVs in Low Voltage Grids. In Proceedings of 2017 IEEE Transportation Electrification Conference (pp. 684-689). IEEE. https://doi.org/10.1109/ITEC.2017.7993352

\section{General rights}

Copyright and moral rights for the publications made accessible in the public portal are retained by the authors and/or other copyright owners and it is a condition of accessing publications that users recognise and abide by the legal requirements associated with these rights.

- Users may download and print one copy of any publication from the public portal for the purpose of private study or research.

- You may not further distribute the material or use it for any profit-making activity or commercial gain

- You may freely distribute the URL identifying the publication in the public portal 


\title{
Optimal Design of DC Fast-Charging Stations for EVs in Low Voltage Grids
}

\author{
Marjan Gjelaj, Chresten Træholt, Seyedmostafa Hashemi, Peter Bach Andersen \\ EVLabDK-CEE Department of Electrical Engineering \\ Technical University of Denmark - Copenhagen, Denmark \\ Email: margje@elektro.dtu.dk, ctr@elektro.dtu.dk,shtog@elektro.dtu.dk,pba@elektro.dtu.dk
}

\begin{abstract}
DC Fast Charging Station (DCFCS) is essential for widespread use of Electric Vehicle (EVs). It can recharge EVs in direct current in a short period of time. In recent years, the increasing penetration of EVs and their charging systems are going through a series of changes. This paper addresses the design of a new DCFCS for EVs coupled with a local Battery Energy Storage (BES). DCFCS is equipped with a bidirectional AC/DC converter for feeding power back to the grid, two lithium batteries and a DC/DC converter. This paper proposes an optimal size of the BES to reduce the negative impacts on the power grid through the application of electrical storage systems within the DC fast charging stations. The proposed solution decreases the charging time and the impact on the low voltage (LV) grid significantly. The charger can be used as a multifunctional grid-utility such as congestion management and load levelling. Finally, an optimal design of the DCFSC has been done to evaluate the feasibility and the operability of the system in different EVs load conditions.
\end{abstract}

Keywords-DC fast charging station, battery energy storage, electric vehicle.

\section{INTRODUCTION}

European cities are increasing driving restrictions on gasoline vehicles and replacing them with electric vehicles (EVs) as a responsible alternative to reduce the $\mathrm{CO} 2$ emotions. Many factors are contributing to the spread of electric transportation, and the sector is starting to benefit from incentives given by individual governments and European Commission [1]. Considering the growing number of EVs, it seems necessary to establish a smart DC fast charging infrastructure to provide their required energy demand in a short period of time. The EN/IEC 61851 and automotive engineers in U.S. SAE J1772 have proposed their standards on the charging modes for EVs and the maximum current delivered in DC [2]. According to the international standards, there are different charging modes classified as mode 1, 2, 3 and 4 for the EV conductive charging system. IEC 61851 applies to on-board and off-board equipment for charging electric vehicles and providing electrical power for any additional services on the vehicle if required when connected to the electrical grid. One method for EV charging is to connect the AC supply network to an on-board charger, the power delivered is between $7 \mathrm{~kW}$ and $43 \mathrm{~kW}$ [3]. The charging rate requires about 2-3 hours to store the energy needed to cover $150 \mathrm{~km}$. Another method to recharge EVs is to use an off-board charger for delivering direct current, to recharging in a short period of time. In addition the charging facilities operating at high power levels. Currently, the delivered power in DC is between $50 \mathrm{~kW}$ and $120 \mathrm{~kW}$ for public charging stations with a charging rate about $45 \mathrm{~min}$ and $30 \mathrm{~min}$ to store energy for $150 \mathrm{~km}$ of driving. The fast charging station has met implementation difficulties in the major European cities, because its progress poses demanding requirements in terms of EV battery and charging rate restrictions. In addition, there are many issues related to the impact of the DC fast charging on the distribution network in the low voltage (LV), such as control the congestion during the peak hours and the high losses among the feeders [4]. The widespread use of EVs and especially the installations of the fast charger requires investigating on the distribution grid impact. So far, many studies have been done about the EVs and their grid impact.

To address this issue, research is moving in various directions, for example in some papers, a coordinated charging system is proposed to minimize the power losses and maximize the main grid load force for an optimal charging profile for EVs and plug-in hybrid electric vehicles (PHEVs) [5]. To mitigate the congestion form EVs, other studies have proposed dynamic price for the uses to keep the reliability of the electrical grid [6]. N.G. Paterakis has developed a detailed energy management system structured for unpredictable load such as EVs and PHEVs. He has determined the optimal day-ahead appliance scheduling of a smart-load based hourly pricing and peak power limiting based on a demand response strategies [7]. Other authors have focused their studies on the impact of the charging stations based on simulation models. The models determine the spatial distribution of different charging stations to evaluate the potential for load shifting EVs demand [8]. Although the DC fast charging station has a deep impact on the grid and at the moment few researcher are working to determine the fast charging stations' demand.

It is very important to design an appropriate fast charging station for EVs, which is able to meet the expected demand. Designing an appropriate charging station in LV grid requires not only meeting the charging demand at any time of the day, but also minimizing the station operation costs [9]. Especially, in LV grid where the operators are focused to minimized the losses and to reduce the size of the electrical lines and avoid the network congestion. The load curve profile of the DC fastcharging station can increases significantly the peak load demand as well as high connection fees to grid operators in order to offset the cost of larger transformers and electrical equipment. Some recent studies have focused on using battery energy storage as a buffer between the grid and the charging stations in 
order to reduce their peak consumption [10], but more work is required on the optimal size of BES in the station. In this paper, the authors attempt to determine the optimal design of the DC fast charging station to reduce their grids impact. In particular, we propose a new design of a stationary battery energy system that physically decouples a DC fast charging from an LV distribution.

The rest of the manuscript is organized as follows. In Section II conductive charging modes and in the Section III charging station design and demand modelling. Section IV the description of the optimal design of the BES is given in Section IV and V, respectively with the simulation results. Finally, in Section VI the conclusions with the optimal size of the BES within the DC fast-charging stations and its practical implementation in LV grids.

\section{CONDUCTIVE CHARGING MODES IEC61851}

According to IEC 61851 there are four charging modes classified as mode 1, 2, 3 and 4 [3] for EV conductive charging. IEC 61851 applies to on-board and off-board equipment for charging electric vehicles and providing electrical power for any additional services on the vehicle if required when connected to the electrical grid. One method for charging EVs is to connect the AC supply network to an on-board charger. An alternative method is to use an off-board charger for delivering direct current, for charging in a short period of time. Special charging spots are operating at high power levels by using medium voltage (MV). The EV charging modes are the following: Charging Mode 1: homes and offices, Charging Mode 2: private facilities. Charging Mode 3: public charging stations. Charging Mode 4: public charging stations. The mode 4 has been implemented for the AC/DC charging by the use of off-board chargers. Typical at the moment the charging time of the mode 4 is from 50 to 30 minutes to reach $80 \%$ of battery SoC with a power between 50 and $120 \mathrm{~kW}$. Figure 1 summarizes the main characteristics of the charging modes with their respective powers according to IEC 61851 and IEC 62196 [2]-[3]. The IEC 62196 applies to plugs, socket-outlets, and connectors which use conductive charging.

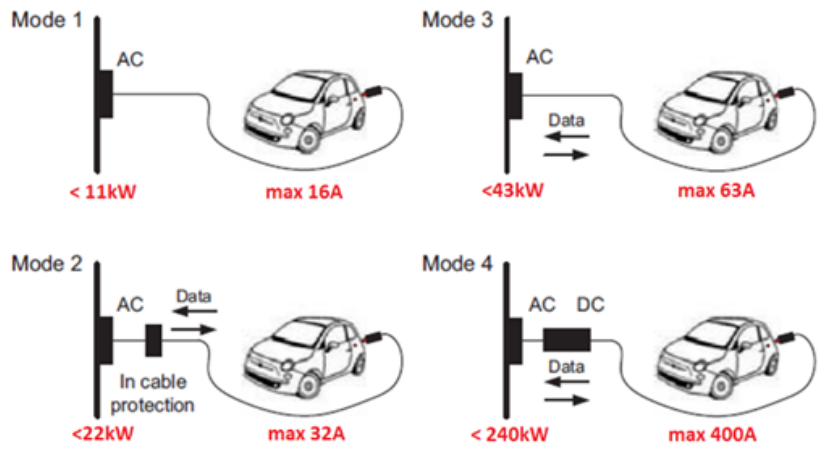

Figure 1. DC - Fast charging station in mode 1, 2, 3 and 4

In the European cities, the charging systems most used at the moment are mode 2 and mode 3, for the following reasons: low infrastructure costs, electrical grid and international standards availability. The AC charging architecture is robust, but it has power limitations of $43 \mathrm{~kW}$. Furthermore, recharging in $\mathrm{AC}$ entails high conversion losses on the EV side. The efficiency of an on-board converter is around $85 \%$ and this represents an increasing energy demand from the $\mathrm{EV}$ in order to reach $80 \%$ of SoC. In mode 3 the charging rate to reach $80 \%$ of the EV battery with $22 \mathrm{~kW}$ takes approximately 1 hour with a vehicle of $20 \mathrm{kWh}$. To solve the problem of the low range, the major car manufacturers are increasing the battery pack of the new models form $20 / 25 \mathrm{kWh}$ to $40 / 60 \mathrm{kWh}$ such as Tesla model 3 and eGolf. Therefore charging in $\mathrm{AC}$ will represent an issue for the long charging time and in particular space congestion of the public parking. Recently, some company are starting to develop new fast charging systems in DC because the standard allows charging with $400 \mathrm{~A}$ and maximum power of $240 \mathrm{~kW}$ in Chademo and Combined Charging System (Combo). The state of art at the moment is the following: $120 \mathrm{~kW}$ by Tesla connected in MV (outside the cities), $50 \mathrm{~kW}$ by $\mathrm{ABB}$ with combo in LV (inside the cities), $62.5 \mathrm{~kW}$ by Chademo system in LV (inside the cities), $150 \mathrm{~kW}$ ABB with combo in MV (outside the cities). Mode 4 significantly reduces the charging time and the conversion losses on the EV side.

\section{CHARGING STATION DESIGN AND DEMAND MODELLING IN LV GEIDS}

Two DC charging stations of $240 \mathrm{~kW}$ might require the connection in MV with a high investment costs Figure 2. The new dedicated line and the transformer have high economic costs and space restrictions, especially if the installation takes place in the cities [9].

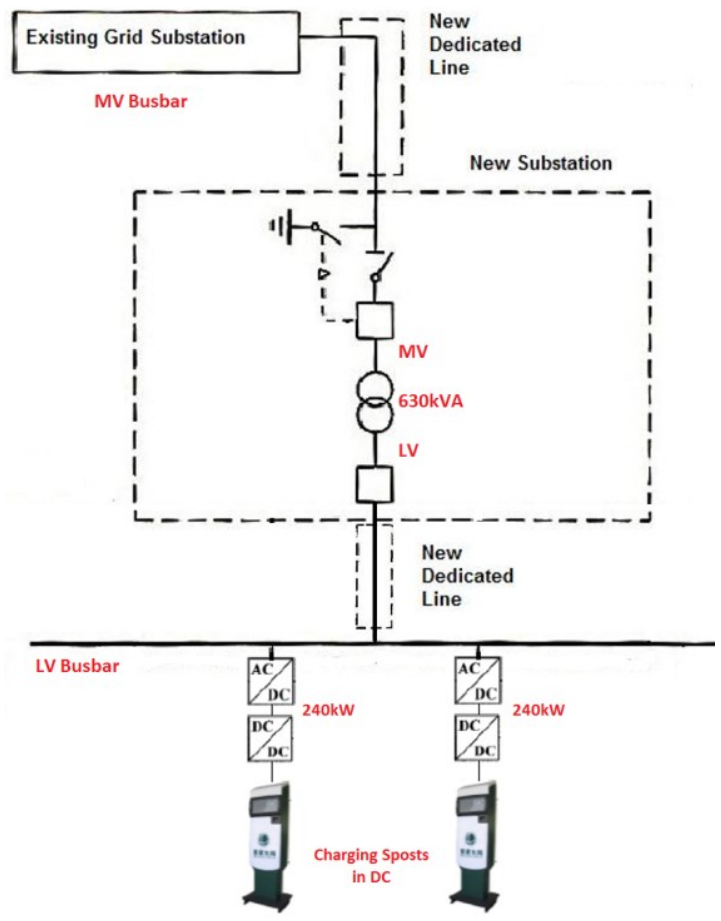

Figure 2. New connection in MV for DC-fast charging stations 
The DCFCS in combination with the BES can represent a reliable solution to avoid the connection in MV especially within residential areas. The annual cost reduction of BEVs has been estimated around 8\% [11]-[12]. This represents a chance to evaluate possible scenarios of the DCFCS in order to develop a smart charging station and control methods for these flexible loads [13].

In addition, DCFCS with the BESs gives the opportunity to the users to recharge the EVs up to $80 \%$ of their SOC with charging rate of $9-10$ minutes. The new design of the charging stations is based on the installation of two identical battery energy system (BES1 and BES2) that physically decouples a DC fast charging station (DCFCS) from an LV distribution grid, as shown in Figure 4.

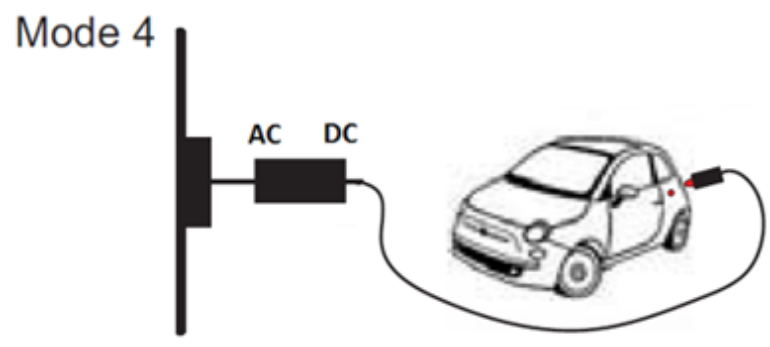

Figure 3. DC fast charging station in mode 4 without BES

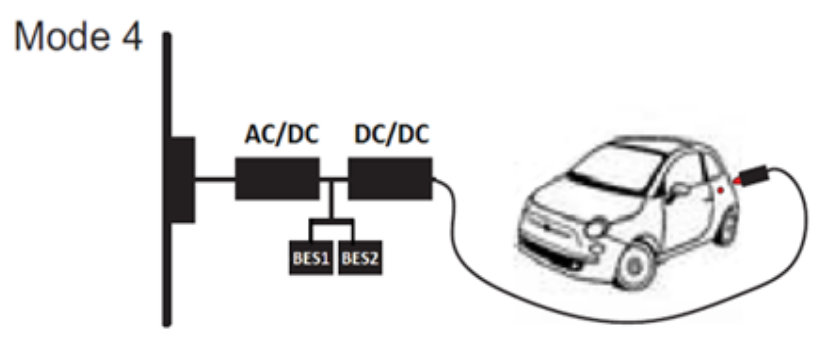

Figure 4. DC fast charging station in mode 4 with BESs

The operation of such a system is based on successive switches of the BES connections that allow one of the batteries (BES2) to be charged from the grid while the other (BES1) is charging an EV, as shown in Figure 5.

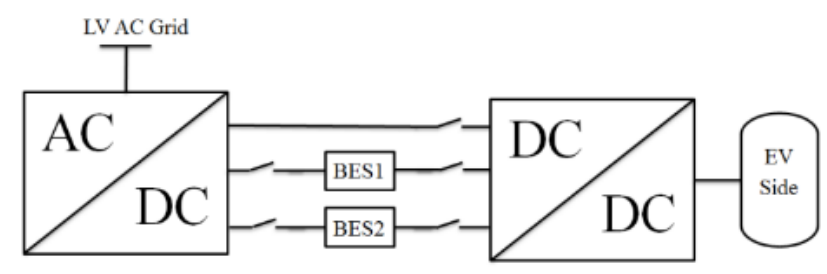

Figure 5. DC fast charging station in LV grids with BESs

\section{OPTIMAL DESIGN OF BESS IN FUNCTION OF CHARGING DEMAND}

The charging station will have one or more charging slots, and each of them can be connected in the LV grid with a minimum power of $100 \mathrm{~kW}$ required form the grid in AC. Every $\mathrm{EV}$ has a nominal capacity given by the manufacturers that represents an amount of kilometres that the car can reach with specific driving conditions. According to the tests performed in the EV laboratory, only $90 \%$ of the nominal capacity is used as work capacity. To make the EV demand study more realistic, the following steps are made: SoC of the EV battery is fixed at $25 \%$ SoC (worst case). The EVs load demand capacity is between: $7.2 \mathrm{kWh}$ and $36 \mathrm{~kW}$, Table 1:

\section{TABLE I.}

COMPARISON OF DIFFERENT COMMERCIAL EVS

\begin{tabular}{|c|c|c|c|c|c|c|}
\hline $\begin{array}{c}\text { Models } \\
\text { (2015- } \\
\text { 2017) } \\
\end{array}$ & $\begin{array}{r}\text { Range } \\
{[\mathrm{km}]}\end{array}$ & $\begin{array}{r}\text { Battery } \\
{[\mathrm{kWh}]}\end{array}$ & $\begin{array}{l}\text { Usable } \\
\text { battery } \\
{[\mathrm{kWh}]}\end{array}$ & $\begin{array}{c}\text { SoC } \\
25 \% \\
{[\mathrm{kWh}]}\end{array}$ & $\begin{array}{c}\text { SoC } \\
80 \% \\
{[\mathrm{kWh}]}\end{array}$ & $\begin{array}{c}\Delta \\
\text { load } \\
{[\mathrm{kWh}]}\end{array}$ \\
\hline $\begin{array}{l}\text { Mitsbuishi } \\
\text { i-MiEV }\end{array}$ & 100 & 16 & 14.4 & 3.6 & 10.8 & 7.2 \\
\hline $\begin{array}{c}\text { Smart } \\
\text { Electric }\end{array}$ & 110 & 17 & 15.3 & 3.8 & 11.5 & 7.7 \\
\hline $\begin{array}{c}\text { Chevy } \\
\text { Spark EV }\end{array}$ & 130 & 20 & 18 & 4.5 & 13.5 & 9 \\
\hline $\begin{array}{c}\text { BMW } \\
\text { i3 }\end{array}$ & 130 & 22 & 19.8 & 4.95 & 14.9 & 10 \\
\hline $\begin{array}{c}\text { Ford } \\
\text { Focus EV }\end{array}$ & 130 & 23 & 20.7 & 5.17 & 15.5 & 10.33 \\
\hline $\begin{array}{l}\text { Fiat } \\
500 \mathrm{e}\end{array}$ & 140 & 24 & 21.6 & 5.4 & 16.2 & 10.8 \\
\hline $\begin{array}{c}\text { Leaf } \\
24 \mathrm{kWh}\end{array}$ & 130 & 24 & 21.6 & 5.4 & 16.2 & 10.8 \\
\hline $\begin{array}{c}\text { Leaf } \\
30 \mathrm{kWh}\end{array}$ & 165 & 30 & 27 & 6.75 & 20.3 & 13.55 \\
\hline $\begin{array}{c}\text { Kia Soul } \\
\text { EV }\end{array}$ & 150 & 30 & 27 & 6.75 & 20.3 & 13.55 \\
\hline $\begin{array}{l}\text { Mercedes } \\
\text { BClassEV }\end{array}$ & 170 & 36 & 32.4 & 8.1 & 24.3 & 16.2 \\
\hline $\begin{array}{c}\text { VW } \\
\text { eGolf }\end{array}$ & 300 & 37 & 33.3 & 8.3 & 25 & 16.7 \\
\hline $\begin{array}{l}\text { Tesla } \\
\text { S } 60\end{array}$ & 340 & 60 & 54 & 13.5 & 40.5 & 27 \\
\hline $\begin{array}{c}\text { Tesla } \\
\text { model } 3\end{array}$ & 350 & 60 & 54 & 13.5 & 40.5 & 27 \\
\hline $\begin{array}{c}\text { Tesla } \\
\text { modelS80 }\end{array}$ & 450 & 80 & 72 & 18 & 54 & 36 \\
\hline
\end{tabular}

The following statistical calculations are carried out to evaluate EVs load demand in different confidence intervals (2):

$$
\begin{gathered}
\text { Sample mean: } \bar{X}_{n}=\frac{1}{n} \sum_{i=1}^{n} X_{i}=15.42 \mathrm{kWh}, \text { with } \mathrm{n}=14 \\
\text { Sample variance: } s_{n}^{2}=\frac{1}{n-1} \sum_{i=1}^{n}\left(X_{i}-\bar{X}_{n}\right)^{2}
\end{gathered}
$$




$$
s_{n}^{2}=\frac{1}{n-1} \sum_{i=1}^{n}\left(X_{i}-\bar{X}_{n}\right)^{2}=\frac{1}{14-1} \sum_{i=1}^{14}\left(X_{i}-\bar{X}_{14}\right)^{2}=107.65
$$

and

$$
s=\sqrt{107.75}=10.375
$$

The confidence interval is 0.95 of BES $\in X$, with $n=14$, the confidence interval is:

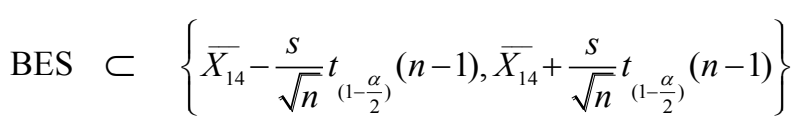

The estimation of the BES size is calculated with this expression and student's t distribution (3):

$$
\begin{gathered}
F(t)=\int_{-\infty}^{t} \frac{\Gamma\left(\frac{(n+1)}{2}\right.}{\Gamma(n / 2) \sqrt{\pi n}\left(1+\frac{x^{2}}{n}\right)^{(n+1) / 2}} \\
1-\alpha=0.95, \\
\alpha=0.05, \mathrm{t} \rightarrow \mathrm{t}\left(1-\frac{\alpha}{2}\right)=t(0.975)^{13}=2.16
\end{gathered}
$$

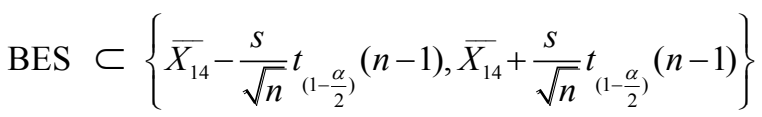

$$
\begin{aligned}
& \mathrm{BES} \subset\left\{1 \overline{5.42}-\frac{10.375}{\sqrt{15}} 2.16,1 \overline{5.42}+\frac{10.375}{\sqrt{15}} 2.16\right\}
\end{aligned}
$$

$$
\{9.634,21.2\} \mathrm{kWh}
$$

If the confidence interval is 0.99 of $B E S \in X$ with $n=14$, the confidence interval is (4):

$$
\begin{gathered}
\mathrm{BES} \subset\left\{1 \overline{5.42}-\frac{10.375}{\sqrt{15}} 3.012,1 \overline{5.4} 2+\frac{10.375}{\sqrt{15}} 3.012\right\} \\
\{7.35,23.5\} \mathrm{kWh}
\end{gathered}
$$

In this case study there are two criteria to size the BESs: Fist, considering EVs SoC at $80 \%$ and to cover $78 \%$ of the EVs demand and the BES should be sized around $23.5 \mathrm{kWh}$. Second, it is important to take into account the number of

\begin{tabular}{|c|c|c|c|c|c|}
\hline $\begin{array}{c}\text { BES } \\
{[\mathrm{kWh}]}\end{array}$ & $\begin{array}{c}{[\%] \text { of }} \\
\text { EVs } \\
\text { charged } \\
\text { up to } 80 \%\end{array}$ & $\begin{array}{c}\text { [\%] of } \\
\text { EVs } \\
\text { charged } \\
\text { up to } 70 \%\end{array}$ & $\begin{array}{c}\text { Average } \\
{[\mathrm{km}] \text { with }} \\
0.1 \\
\mathbf{k W h} / \mathbf{k m}\end{array}$ & $\begin{array}{c}\text { Average } \\
\text { [km] of } \\
\text { EVs with } \\
\text { SoC } 25 \% \\
\end{array}$ & $\begin{array}{l}\text { Total } \\
{[\mathrm{km}]}\end{array}$ \\
\hline 23.5 & $78 \%$ & $93 \%$ & 235 & 45 & 280 \\
\hline 21.5 & $78 \%$ & $93 \%$ & 215 & 45 & 260 \\
\hline 19.5 & $78 \%$ & $78 \%$ & 195 & 45 & 240 \\
\hline 17.5 & $78 \%$ & $78 \%$ & 175 & 45 & 220 \\
\hline 16 & $78 \%$ & $78 \%$ & 160 & 45 & 205 \\
\hline 15.5 & $75 \%$ & $78 \%$ & 155 & 45 & 200 \\
\hline 15 & $65 \%$ & $78 \%$ & 150 & 45 & 195 \\
\hline 13.5 & $50 \%$ & $78 \%$ & 135 & 45 & 180 \\
\hline 11.5 & $50 \%$ & $64 \%$ & 115 & 45 & 160 \\
\hline 9.5 & $22 \%$ & $50 \%$ & 95 & 45 & 140 \\
\hline
\end{tabular}
kilometers needed for driving in the city instead of their SoC at
$80 \%$, moreover the DCFCS is designed to be installed in the cities. Table 2 shows the results of different BES and the energy in terms of kilometers provided by the BES. The driving efficiency of the new EVs model between 2020 and 2025 will be around $0.1 \mathrm{kWh} / \mathrm{km}$.

TABLE II. OPTIMAL SIZE OF THE BES IN FUNCTION OF EVS SOC SATISFACTION

To satisfy the energy demand form EVs, the optimal BES for an DCFCS is $16 \mathrm{kWh}$ because it meets the highest level of SoCs satisfaction. In addition, according to Danish National Transport Survey, the average Danish driving distance is around $29.48 \mathrm{~km}$ per day, therefore $205 \mathrm{~km}$ are sufficient for driving in the city and outside. Each BES has been oversized of $19.2 \mathrm{kWh}$ (Figure 6) because it cannot exceeding 20\% SoC for two reasons: overheating issues and faster degradation of the battery.

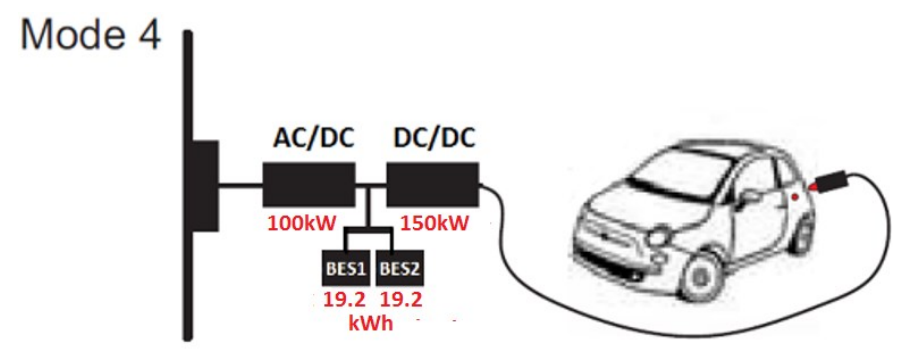

Figure 6. Optimal design of a DCFCS for EVs 
The case study uses an AD/DC converter of $100 \mathrm{~kW}$ and charging rate of $6 \mathrm{C}(9.7 \mathrm{~min})$. The discharging rate through the $\mathrm{DC} / \mathrm{DC}$ is $9 \mathrm{C}(6.7 \mathrm{~min})$ with a converter of $150 \mathrm{~kW}$.

\section{Simulation RESUlts}

The reliability of the system and the performance of the DCFCS are evaluated by a 11-minute simulation in Matlab/ Simulink. A boost converter controls the DC/DC converter through the PI controllers. The boost converter helps to keep the voltage limits constant to ensure the stability of the system for each SoC of the EVs.

\section{A. The charging process of the BESs}

When the BES2 is charging an EV at 9C, the BES1, if previously discharged, can be recharged through the grid with the $\mathrm{AC} / \mathrm{DC}$ converter at $100 \mathrm{~kW}$ and a charging rate of $6 \mathrm{C}$ as shown in Figure 5.
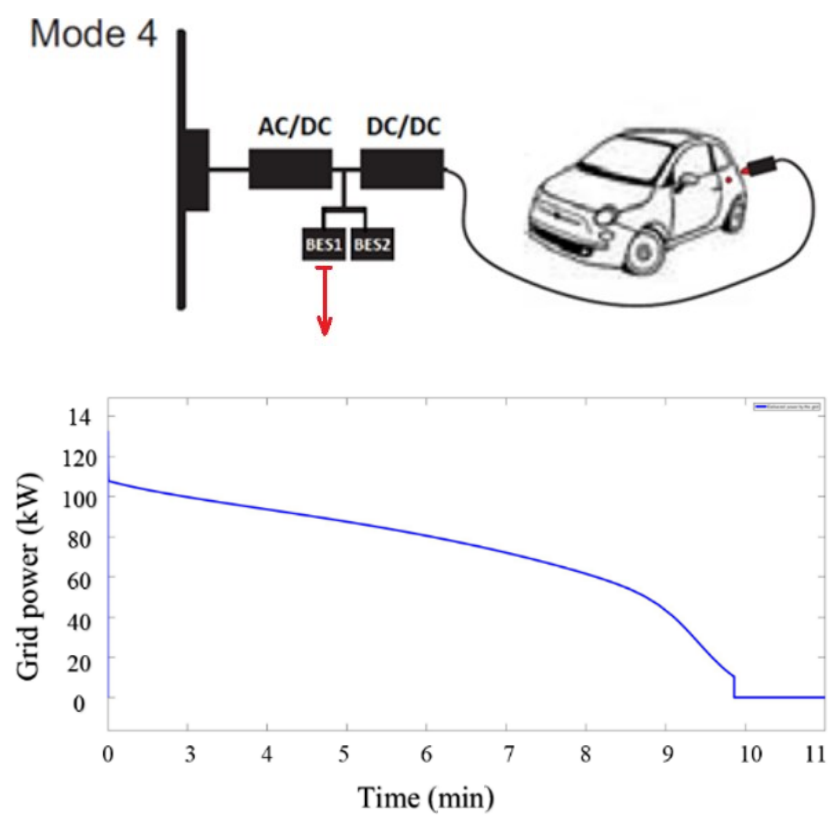

Figure 7. Active power delivered by the LV grid

\section{B. The charging process of an $\mathrm{EV}$}

The graph in Figure 6 shows the charging process of an EV through BES2 and the power absorbed by the electric vehicle. As previously mentioned, the DCFCS has been designed to be used in LV grids, mainly in the cities. It can recharge each vehicle up to $80 \%$ of their SoC in a time period of between 6 minutes and 7 minutes, depending on the SoC of each EV. The functionality of the charging system has been evaluated on a large scale by comparing different commercial EVs with different batteries. The case studies take into account several models from 2015 to 2017 with battery pack between $16 \mathrm{kWh}$ and $80 \mathrm{kWh}$. As shown in table 1 below. All the EVs could be charged by the DCFCS with $150 \mathrm{~kW}$ through the BESs. The results associated with the capability of the DCFCS and its limits in order to supply energy to the end users is shown in Figure 5.
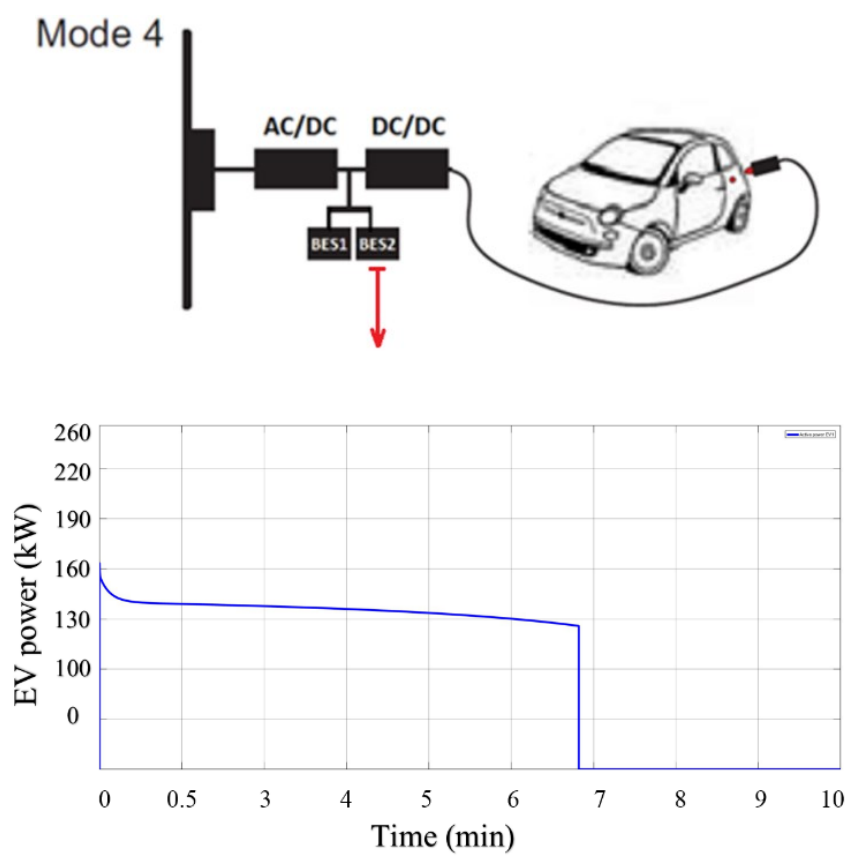

Figure 8 . Active power absorbed by the EV

\section{Capability of the DCFCS}

Figure 9 represents the charging limit of the DCFCS and the capability to recharge EVs up to $80 \%$ in function of their SoCs and battery packs. The DCFCS can provide to recharge EVs at $80 \%$ of SoC with maximum EVs battery pack of $40 \mathrm{kWh}$. For large EVs battery pack such as Tesla models of $60 / 80 \mathrm{kWh}, \mathrm{EV}-$ Van and EV-suv, the DCFCS can recharger them fast up to $50 / 60 \%$ their SoC with more then $250 \mathrm{~km}$ of driving. If the users need more driving kilometers or they want to reach $80 \%$ of the SoC with $450-500 \mathrm{~km}$ the EVs could be recharge twice with a charging time around $20 \mathrm{~min}$.

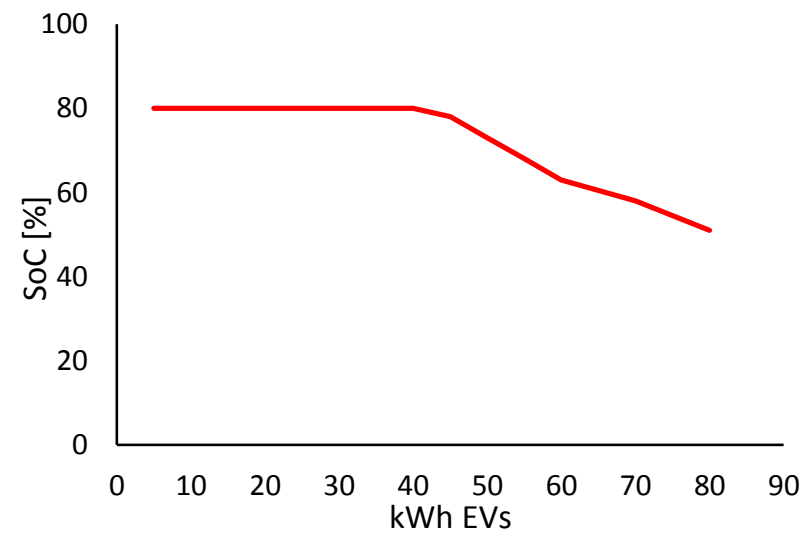

Figure 9. Charging limit of the DCFCS with EVs at $25 \% \mathrm{SoC}$ 


\section{CONCLUSIONS}

This paper introduced an optimal size of the BES within the DC-fast charging stations with the objective of decoupling the LV grid from the peak load demand from EVs.

The research activities have shown that the DCFCS could be decupled from the LV grid with the goal of minimizing the connection costs of the grid by using the BESs. In addition, the advantage of this charging station is to reduce the charging time and grid impact during the peak demand. Results show the following main conclusions:

1. The grid impact of the DCFCS grows with the EV market penetration and the integration of the BESs will avoid the connection costs in MV especially within residential areas.

2. The load levelling control by the installation of intermediate battery helps to reduce the power from the grid connection at $34 \%$.

3. The DCFCS provides the possibility of more than $200 \mathrm{~km}$ driving in less than 10 minutes. It means maximize the user satisfaction minimize the costs form the DCFCS-operators for the public parking lots.

4. The optimal size of the BES will depend from: grid constraint, charging time, SoC satisfaction and EV battery packs.

5. This paper did not take into account optimal storage solution in terms of: lifetime, costs and volumes for the DCFCS. A possible solution could be to use the second life batteries for ancillary services such as primary frequency control or voltage support by using the bidirectional $\mathrm{AC} / \mathrm{DC}$ converter.

To conclude, an optimal control of the DC/DC has to be implemented with a coordinated strategy to estimate periodically the EVs SoC and the load demand. The IEC 61851 and IEC15118 define the general requirements for the control communication between the DC-charger and the EVs, which could provide the charging/discharging process of the BESs. As a future consideration and thanks to a coordinated control strategy of the BESs, we will propose a DC fast-charging station capable of recharging a large number of EVs fast in LV grids by using load demand prediction in function of EVs SoC.

\section{ACKNOWLEDGMENTS}

Marjan Gjelaj is a $\mathrm{PhD}$ student supported by the Danish Research Project EUPD "EnergyLab Nordhavn - New Urban Energy Infrastructures - City of Copenhagen". More information at www.energylabnordhavn.dk and Electric Vehicle Lab (EVlab) at www.powerlab.dk/Facilities/ElectricVehicle-Lab. The EVlab has been established to support a wide array of EV integration and technology services.

\section{REFERENCES}

[1] European commission "mobility and transport" www.ec.europa.eu/transport/home_en.

[2] IEC 62196: Connectors for conductive charging of electric vehicles.

[3] IEC 61851: Conductive charging system / DC EV charging station.

[4] J. Hu, S. You, M. Lind, and J. Østergaard, "Coordinated charging of electric vehicles for congestion prevention in the distribution grid," Smart Grid, IEEE Transactions on, vol. 5, no. 2, pp. 703, March 2014.

[5] K. Clement, E. Haesen, and J. Driesen, "Coordinated charging of multiple plug-in hybrid electric vehicles in residential distribution grids," in Proc. IEEE PES Power Syst. Conf. Expo. (PSCE), Mar. 2009, pp. 1-7.

[6] S. Martinenas, A. B. Pedersen, M. Marinelli, P. B. Andersen, C. Træholt, "Electric Vehicle Smart Charging using Dynamic Price Signal" IEVC, 2014 IEEE International, pp.1-5, Florence,17 Dec. 2014.

[7] N. G. Paterakis, O. Erdinç, A. G. Bakirtzis, and J. P. S. Catalão, “Optimal household appliances scheduling under day-ahead pricing and loadshaping demand response strategies," IEEE Trans. Ind. Informat., vol. 11, no. 6, pp. 1509-1519, Dec. 2015.

[8] C. J. R. Sheppard, A. Harris, and A. R. Gopal, "Cost-effective siting of electric vehicle charging infrastructure with agent-based modeling," IEEE Trans. Transport. Electrific., vol. 2, no. 3, Jun. 2016.

[9] Katarina Knezovi', Mattia Marinelli, Paul Codani, Yannick Perez, "Distribution Grid Services and Flexibility Provision by Electric Vehicles: a Review of Options" 978-1-4673-9682, 2015 IEEE International.

[10] Sanzhong Bai and Srdjan M. Lukic," Unified Active Filter and Energy Storage System for an MW Electric Vehicle Charging Station", " IEEE International, pp, vol. 28, no. 12, December 2013

[11] [15] Björn Nykvist1 and Måns Nilsson, "Rapidly falling costs of battery packs for electric vehicles”, DOI: 10.1038/NCLIMATE2564, 2015.

[12] Battery Storage for Renewables: market Status and Technology Outlook," IRENA, Janary, 2015.

[13] Johan S. Vardakas, "Electric Vehicles Charging Management in Communication Controlled Fast Charging Stations" funded by EC FP7/2007-2013, under grant agreement No. 285969 [CODELANCE]. 